\title{
Experimental Investigation on Strength and Behavior of PSC Fiber Reinforced Beams with GGBS
}

\author{
Dr. R L Ramesh ${ }^{1}$, Dr. Nagaraja $P S^{2}$, Raghavendra $\mathbf{R}^{3}$, Gobinath $S^{3}$ \\ ${ }^{I}$ Professor \& Head, Department of Civil Engineering, Don Bosco Institute of Technology, \\ Bengaluru, Karnataka, India \\ ${ }^{2}$ Professor, Faculty of Engineering, Civil Department, UVCE, Bangalore University, Karnataka, \\ India \\ ${ }^{3}$ Assistant Professor, Department of Civil Engineering, Don Bosco Institute of Technology, \\ Bengaluru, Karnataka, India \\ ${ }^{3}$ Assistant Professor, Department of Civil Engineering, Don Bosco Institute of Technology, \\ Bengaluru, Karnataka, India
}

\begin{abstract}
The Concrete is one of the most important products which are efficiently and effectively used in the field of construction. The usage of natural aggregates in the process of production of concrete was high which lead to huge deficiency of availability of the natural aggregates. At the same time production of cements leads to more environmental pollution. Therefore, the production of concrete was altered by vast usage of admixtures and replacements for natural aggregates. In this paper M60 grade concrete is prepared by using GGBS as a partial replacement of cement which is a good strength building mineral admixture, the steel fibers were also introduced in the concrete to improve the strength parameter and for ease of work with concrete and addition of AUROMIX - 400 which is provided by FOSROC chemicals Bengaluru as super plasticizers. The concrete specimens like Cubes and Cylinders were casted and allowed to curing over a nominal curing period of 7, 14 and 28 days to know the basic mechanical properties of the concrete with the above replacements and at the same time RCC beams were also casted and cured, then post tensioned to know the flexural details of this special concrete.
\end{abstract}

Keywords: PSC, Fibre Reinforced Beam, GGBS, Control Beam, Steel Fibres

\section{INTRODUCTION}

In earlier era the construction method was ordinary so use of naturally available sources was sufficient to build a monument. Now we are in a stage that concrete should perform in a greater extent with all aspects required for a monument with less or no usage of naturally available material. This non-conventional concrete is so called as High Performance Concrete or High Strength Concrete. Out of different types of concrete Pre stressed Concrete is one of the high strength concrete and due to addition of steel fibers and GGBS it is more effective in strength compared to conventional concrete. The reinforcement in the concrete can be pre tensioned and post tensioned as well. The reinforcement which is tensioned after concrete is poured to the specimen is post tensioning and if reinforcement is tensioned before the concrete is poured into the specimen is pre tensioning. Cement is replaced by many admixtures in which GGBS is one of the best material which gains more energy under hydration process along with OPC contributing greater part in strength criteria. One more additive material to the concrete in matter of cracks is fibers, in which the steel fibers plays vital role in decreasing cracks and provides more flexural strength to the concrete. The chemical admixture is one of the creative products which is used for improve the workability of the concrete. Although the main aim is to reduce the usage of cement which leads in less production of cements helping in less air pollution.

\section{Literature Review}

- Arvind Nakum et al, They reviewed the potential industrial usage of High Strength Reinforced Concrete Incorporating GGBS and SF to improve construction strength and reduce steel reinforcing requirements. In addition to cement, blast furnace slag (GGBS) was used. It extends the life and improves the tensile strength of concrete. The research focuses on the mechanical and long-term durability qualities of cured high-strength concrete reinforced with steel fibres. As a result, they suggest that GGBS and steel fibres can be utilised in concrete as an ideal alternative for cement to increase the strength and 
stiffness of concrete as well as other qualities, as well as to make concrete more costeffective.

- Hyeong Jae YOON \& Minehiro NISHYAMA carried out research on [3]. Pre tension technology improved flexural performance in their investigation, and SFRC is discussed. SFRC was predicted to have improved tensile qualities like as strength and stiffness. Pretensioned members have been utilized to reduce crack width and deflection under service loads. Steel fibre reinforced concrete pretensioned beams The volumetric fibre ratios of $0.0,0.3$, and 0.5 percent were the most important characteristics in the cyclic loading testing. According to their findings, the maximum flexural strength and initial cracking load of the beams improved by $16.4 \%$ when using steel fibre over those that did not. The maximum flexural strength of the SFRC beam is about $10 \%$ higher than that of conventional concrete. At a load of $25 \mathrm{kN}$, the maximum crack widths on NC, SFRC03, and SFRC05 were $0.17 \mathrm{~mm}, 0.16 \mathrm{~mm}$, and $0.13 \mathrm{~mm}$, respectively.

\section{Summary of Literature Review}

From the literature it is found that the incorporation of steel fibre in concrete helps in redistribution stresses. Steel fibres take up the load as soon as concrete matrix cracks and reduce the propagation of cracks the incorporation of steel fibre increase the tensile strength in concrete, therefore the percentage of steel reinforcement can be reducing. It is found that the addition of GGBS up to $30 \%$ in concrete will increase the substantial gain in compressive and flexural strengths with the age. Cement can be partially substituted by GGBS up to $20 \%$ without significantly reducing flexural strength with a fibre content of $2 \%$. In case of PSC beams, the pre stressing suppress the crack compared that of RCC beams. From the literature it has been found that the optimum percentage of steel fibre is found to as $2 \%$.

\section{Present Scope of the work}

In this study 4 types of each 3 post tensioned beams are casted.

a. Conventional concrete beam (CC)

b. $\mathrm{CC}+10 \%$ of GGBS.

c. $\mathrm{CC}+2 \%$ of steel fibre as a volume of concrete.

d. CC+ $10 \%$ of GGBS $+2 \%$ of Steel fibre as a Volume of concrete

The beams will be tested under static loading condition and the behaviour of each type of beams can be determined and Compared the obtained results.

\section{Objectives of the work}

- To study the ultimate load carrying capacity of post-tensioned.

$>$ Conventional concrete $(\mathrm{CC})$ beam.

$>\mathrm{CC}+10 \%$ of GGBS.

$>\mathrm{CC}+2 \%$ of steel fibre as a volume of concrete.

$>\mathrm{CC}+10 \%$ of GGBS $+2 \%$ of steel fibre as a volume of concrete.

- To study the flexural behaviour of SFRC post tensioned beams with GGBS.

- To study the failure modes, crack widths and crack patterns of above beams.

- To assess the cracking load, maximum load of and compared with reference (CC) beams.

\section{Methodology}

1. Collection of materials and studying basic properties

2. Mix design of M60 grade concrete using these properties.

3. Slump cone test, compressive strength, and split tensile strength tests are performed on fresh and hardened concrete, respectively.

4. Total 12 beams have rectangular cross-section of $3.4 \times 0.23 \times 0.3 \mathrm{~m}$ are casted. Then the beams are cured for 28 days.

5. The beams are post tensioned until required stresses are induced. Out of which one type beam is kept as it is which acts as a reference beam (CC).

6. Then the beams are tested for 2-point static loading case. 
7. The ultimate load carrying capacity, failure modes and behaviour of Post-tensioned beams are compared with that of controlled beams.

Using these test results suitable graphs is plotted. by the obtained test results conclusion are made.

\subsection{3 grade OPC}

\section{Material Characterization}

Table 1. Physical Properties of Cement

\begin{tabular}{|c|c|c|c|}
\hline Sl. No. & Properties & Obtained Values & Requirements as per IS 12269 - 1987 \\
\hline 1. & Fineness & $2.5 \%$ & $10 \%$ \\
\hline 2. & Soundness & $1.5 \mathrm{~mm}$ & $\ngtr 10 \mathrm{~mm}$ \\
\hline 3. & Initial Setting Time & $112 \mathrm{~min}$ & $\nless 39 \mathrm{~min}$ \\
\hline 4. & Final Setting Time & $440 \mathrm{~min}$ & $\ngtr 600 \mathrm{~min}$ \\
\hline & & Compressive Strength \\
\cline { 2 - 4 } & 3 DAYS & $39.5 \mathrm{~N} / \mathrm{mm}^{2}$ & $\nless 27 \mathrm{~N} / \mathrm{mm}^{2}$ \\
\cline { 2 - 4 } 5. & 7 DAYS & $51 \mathrm{~N} / \mathrm{mm}^{2}$ & $\nless 37 \mathrm{~N} / \mathrm{mm}^{2}$ \\
\cline { 2 - 4 } & 28 DAYS & $72 \mathrm{~N} / \mathrm{mm}^{2}$ & $\nless 53 \mathrm{~N} / \mathrm{mm}^{2}$ \\
\hline 6. & Standard Consistency & $31 \%$ & ---- \\
\hline 7. & Specific Gravity & 3.08 & ---- \\
\hline
\end{tabular}

\subsection{Fine Aggregates and Coarse Aggregates}

Table 2. Physical Properties of Fine Aggregates

\begin{tabular}{|l|c|c|}
\hline \multicolumn{3}{|c|}{ Physical Properties of River Sand } \\
\hline 1. & Dry Compacted bulk density & $1652.18 \mathrm{~kg} / \mathrm{m}^{3}$ \\
\hline 2. & Loose bulk density & $1441 \mathrm{~kg} / \mathrm{m}^{3}$ \\
\hline 3. & Specific gravity & 2.73 \\
\hline 4. & Fineness Modulus & 2.89 \\
\hline
\end{tabular}

Table 3. Physical Properties Coarse Aggregates

\begin{tabular}{|c|c|c|}
\hline \multicolumn{3}{|c|}{ Physical Properties } \\
\hline $\mathbf{1 .}$ & Shape & Angular \\
\hline $\mathbf{2 .}$ & Dry compacted bulk density & $1500 \mathrm{~kg} / \mathrm{m}^{3}$ \\
\hline 3. & Loose Bulk Density & $1398 \mathrm{~kg} / \mathrm{m}^{3}$ \\
\hline 4. & Specific Gravity & 2.74 \\
\hline $\mathbf{5 .}$ & Fineness Modulus & 6.70 \\
\hline
\end{tabular}

\subsection{Water}

Normal potable water is used for the concrete mix. Water is the main source the hydration of the cement in concrete. Water should free from alkali content, if it there alkali aggregate reaction will takes place, as a result of this durability of concrete reduces. The $\mathrm{pH}$ of water must be between 6 to 8 . The water free from organic impurities, silt etc. has been used in concrete.

\subsection{Super Plasticizer}

The Auromix-400 which is provided by FOSROC chemicals Bengaluru is used as super plasticizer in concrete. Auromix 400 complies with IS: 9103-1999(2007). It also complies with ASTM C494 Type G depending on the dosage.

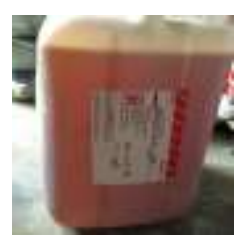

Figure 1. Auromix - 400 


\subsection{GGBS}

It is one of the byproducts obtained from iron industry. It is one of strength increasing mineral admixtures. The GGBS was provided by JSW company for the work.

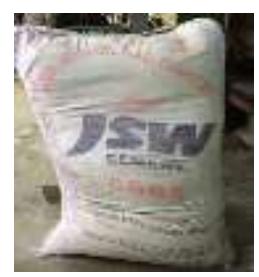

Table 4. Physical Properties of GGBS

\begin{tabular}{|c|c|c|}
\hline Sl. No. & Parameter & Value \\
\hline 1. & Bulk Density & $550-700 \mathrm{Kg} / \mathrm{m}^{3}$ \\
\hline 2. & Bulk Density & $200-350 \mathrm{Kg} / \mathrm{m}^{3}$ \\
\hline 3. & Specific Gravity & 2.61 \\
\hline
\end{tabular}

Figure 2. GGBS

\subsection{Steel Fibre}

The fibres from M/S SHAKTHIMAN MSC 6030, which meet ASTM A820 standards, were employed in this project. Fabricated from Crimped End Fibres with the following specifications, they were used in this project.

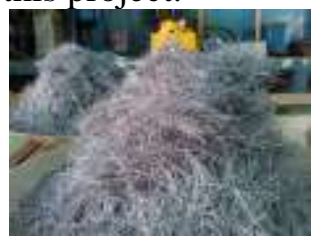

\subsection{Post Tensioning Devices}

Figure 3. Steel Fibre

Anchor plate is made up of cast iron material. In order to enter the pre-stressing strand into the sheathing duct at both ends of the beam, it has a route. Concrete encases this.

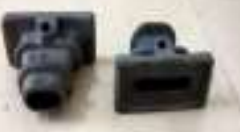

Figure 4. Anchor Plate

Wedges are used to hold the pre stressed strands. This is made out of alloy carbon steel. These wedges slitted into 3 equal parts and work like a split jaws and it contains serrations inside.

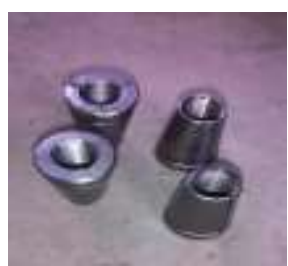

Figure 5. Wedges

Barrels are used to hold the wedges. These are also made out alloy carbon steel.

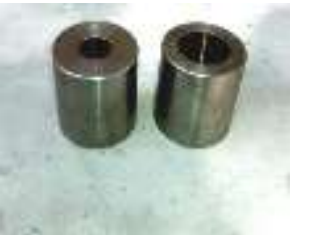

Figure 6. Barrels

The high tensioned strands from MIKI steels Bengaluru The properties of strands is given below. Ultimate tensile strength is about $1960 \mathrm{~N} / \mathrm{mm} 2.7$ ply of $12.7 \mathrm{~mm}$ diameter. 


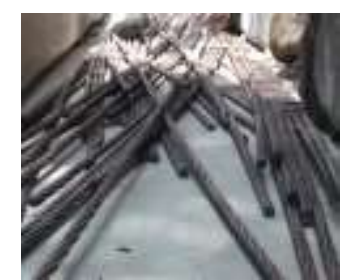

Figure 7. Post Tensioned Strands

Table 5. Slump variations

\begin{tabular}{|c|c|}
\hline Mix Description & Slump Values \\
\hline $\mathrm{CC}$ & $121 \mathrm{~mm}$ \\
\hline $\mathrm{CFi}$ & $110 \mathrm{~mm}$ \\
\hline $\mathrm{CGG}$ & $115 \mathrm{~mm}$ \\
\hline $\mathrm{CGFi}$ & $102 \mathrm{~mm}$ \\
\hline
\end{tabular}

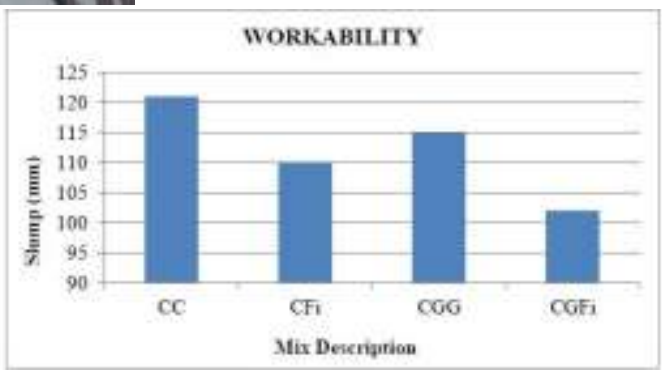

Figure 9. Slump variations

The addition of GGBS decreased the slump values in the tests, which were based on trial mixes. The M60 concrete mixes with admixtures fibre had a slump value of 110 when made with a water cement ratio of 0.3 and a maximum addition of $1 \%$ super plasticizer. As a result, to maintain a medium degree of workability in fibre reinforced concrete, higher dosages of super plasticizers are required.

\section{Compression Test}

In order to find out the concrete's compressive strength, this test is used. It determines the whether the concrete attains required strength at required time. It is commonly used in all the experiments to know the strength of the specimen which is going to attain from the experiment. Normally to find the compressive strength cubes of standard size $(0.15 \times 0.15 \times 0.15) \mathrm{m}$ is used. In this study of work to know the compressive strength, cubes were casted of size $(0.15 \times 0.15 \times 0.15) \mathrm{m}$ is considered and of $\mathrm{M} 60$ grade.

Table 6. Comparison in Compressive Strength with respect to Curing Period and Mix Type

\begin{tabular}{|c|c|c|c|c|c|c|c|}
\hline \multirow{3}{*}{ Sl. No. } & \multirow{3}{*}{ Mix Name } & \multicolumn{6}{|c|}{ Compressive Strength of cubes in N/mm ${ }^{2}$} \\
\hline & & \multicolumn{2}{|r|}{7 Days } & \multicolumn{2}{|r|}{14 days } & \multicolumn{2}{|r|}{28 days } \\
\hline & & $\mathrm{CC}$ & $\mathrm{CC}+10 \% \mathrm{GG}$ & $\mathrm{CC}$ & $\mathrm{CC}+10 \% \mathrm{GG}$ & $\mathrm{CC}$ & $\mathrm{CC}+10 \% \mathrm{GG}$ \\
\hline 1. & $\mathrm{CC}$ & 40.81 & & 61.68 & & 69.84 & \\
\hline 2. & $\mathrm{CFi}$ & 41.55 & & 62.28 & & 70.29 & \\
\hline 3. & CGG & & 41.85 & & 63.53 & & 70.83 \\
\hline 4. & CGFi & & 43.13 & & 64.27 & & 71.64 \\
\hline
\end{tabular}

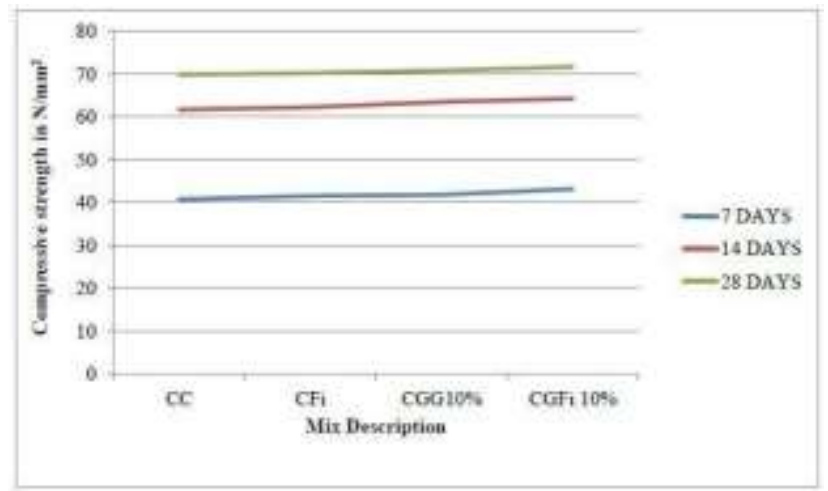

Figure 10. Comparison in compressive strength

It has been observed that with the addition of GGBS compressive strength of concrete at the age of 28 days has been increased. The increase in strength is in the range of $2.57 \%$ for SFRC with GGBS. The results showed that with the addition of fibre and GGBS in concrete the compressive strength of concrete increases compared to normal concrete. 


\section{Flexure Test}

The beam specimens using for this study will be having dimension of $34 \times 0.23 \times 0.3 \mathrm{~m} .2$ bars of $10 \mathrm{~mm}$ dia are provided at the bottom as tension reinforcement, 2 bars of $8 \mathrm{~mm}$ dia are provided at the top as hanger bars and $2 \mathrm{~L}-8 \mathrm{~mm}$ dia stirrups spacing @ $170 \mathrm{~mm} \mathrm{C} / \mathrm{C}$ is used. Additionally, Bursting Tension reinforcement is provided at the end of the beam as end anchorage.

\subsection{Flexural Results Obtained for Control Beam}

The conventional concrete beam was kept as a control beam. The load at the first crack was $86 \mathrm{kN}$, corresponding deflection was found to be $4.962 \mathrm{~mm}$. New cracks are formed as the stress increases, and as a result, the propagation occurs. And finally the ultimate load was found to be $153 \mathrm{kN}$, the corresponding deflection was $24.891 \mathrm{~mm}$.

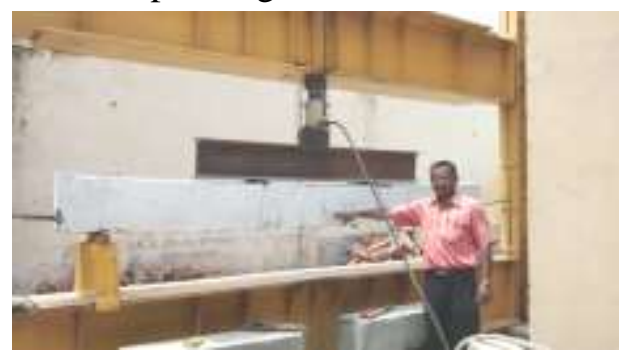

Figure 10. Flexural test

Table 7. Test results of control beam

\begin{tabular}{|l|l|c|}
\hline & \multicolumn{1}{|c|}{ Beam designation } & Control beam \\
\hline 1 & Load at first crack (Pcr) & $86 \mathrm{KN}$ \\
\hline 2 & Centre deflection at first crack & $4.962 \mathrm{~mm}$ \\
\hline 3 & Ultimate load $(\mathrm{Pu})$ & $153 \mathrm{KN}$ \\
\hline 4 & Centre deflection at ultimate load & $24.891 \mathrm{~mm}$ \\
\hline 5 & First crack width & $0.6 \mathrm{~mm}$ \\
\hline
\end{tabular}

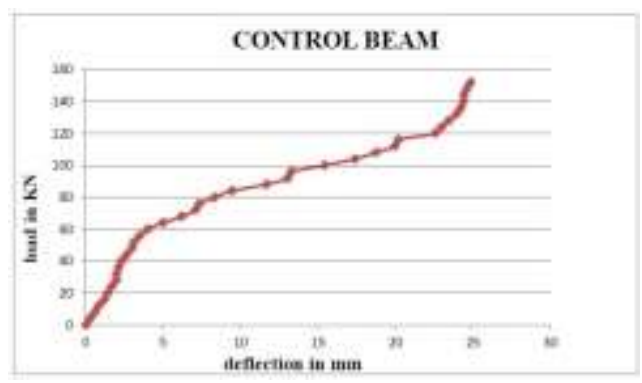

Figure 11. Load v/s deflection

\subsection{Flexural Results obtained for Beam with Partial Replacement of GGBS}

The load at the first crack was $90 \mathrm{KN}$, corresponding deflection was found to be $4.414 \mathrm{~mm}$. New cracks appeared as a result of the increased load, and crack propagation occurred as a result. And finally the ultimate load was found to be $174 \mathrm{KN}$, the corresponding crack deflection was 21.863 mm.

Table 8. Test results of beam with GGBS

\begin{tabular}{|l|l|l|}
\hline & Beam designation & CC+10\%GGBS \\
\hline 1 & Load at first crack (Pcr) & $90 \mathrm{KN}$ \\
\hline 3 & Centre deflection at first crack & $4.414 \mathrm{~mm}$ \\
\hline 4 & Ultimate load $(\mathrm{Pu})$ & $174 \mathrm{KN}$ \\
\hline 5 & $\begin{array}{l}\text { Centre deflection at ultimate } \\
\text { load }\end{array}$ & $21.863 \mathrm{~mm}$ \\
\hline 5 & First crack width & $0.4 \mathrm{~mm}$ \\
\hline
\end{tabular}

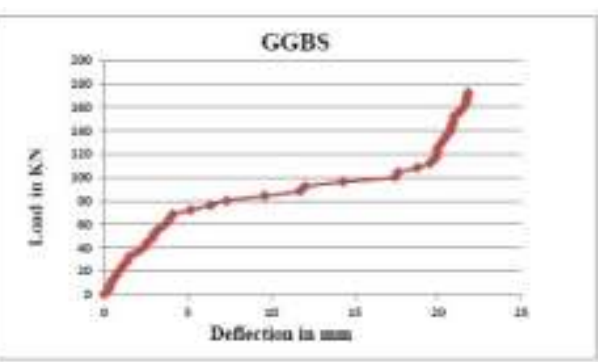

Figure 12. Load v/s Deflection (beam with GGBS)

\subsection{Flexural Results obtained for Beam Incorporated with Steel Fibre}

The load at the first crack was $96 \mathrm{KN}$, corresponding deflection was found to be $4.197 \mathrm{~mm}$. New cracks appeared as the load increased. And finally the ultimate load was found to be $180 \mathrm{KN}$, the corresponding crack deflection was $18.516 \mathrm{~mm}$.

Table 12. Test results of beam with Steel Fibres

\begin{tabular}{|c|l|l|}
\hline 1 & Beam designation & $\begin{array}{l}\mathrm{CC}+2 \% \text { Steel } \\
\text { fibre }\end{array}$ \\
\hline 2 & Load at first crack (Pcr) & $96 \mathrm{KN}$ \\
\hline 3 & Centre deflection at first crack & $4.197 \mathrm{~mm}$ \\
\hline 4 & Ultimate load $(\mathrm{Pu})$ & $180 \mathrm{KN}$ \\
\hline
\end{tabular}

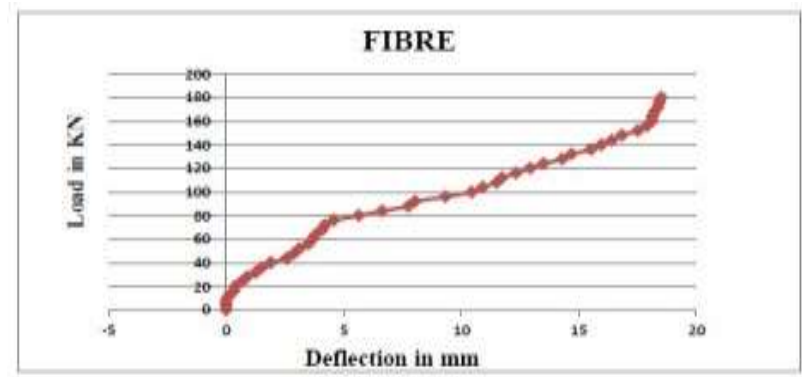




\begin{tabular}{|c|l|l|}
\hline 5 & Centre deflection at ultimate load & $18.516 \mathrm{~mm}$ \\
\hline 6 & First crack width & $0.36 \mathrm{~mm}$ \\
\hline
\end{tabular}

Figure 13. Load v/s Deflection (beam with steel fibres)

\subsection{Flexural Results obtained for Beam Incorporated with Steel Fibre and GGBS}

The load at the first crack was $104 \mathrm{KN}$, corresponding deflection was found to be $2.616 \mathrm{~mm}$. New cracks appeared as the load increased. And finally the ultimate load was found to be $196 \mathrm{KN}$, the corresponding crack deflection was $15.446 \mathrm{~mm}$.

Table 12. Test results of beam with Steel Fibres with GGBS

\begin{tabular}{|l|l|l|}
\hline 1 & Beam designation & $\begin{array}{l}\text { CC+2\%Steel } \\
\text { fibre+10\%GGBS }\end{array}$ \\
\hline 2 & Load at first crack (Pcr) & $104 \mathrm{KN}$ \\
\hline 3 & Centre deflection at first crack & $2.616 \mathrm{~mm}$ \\
\hline 4. & Ultimate load $(\mathrm{Pu})$ & $196 \mathrm{KN}$ \\
\hline 5 & Centre deflection at ultimate load & $15.446 \mathrm{~mm}$ \\
\hline 6 & First crack width & $0.3 \mathrm{~mm}$ \\
\hline
\end{tabular}

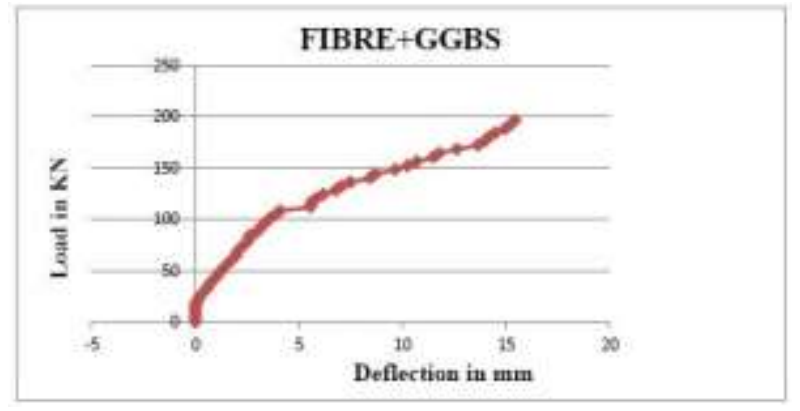

Figure 14. Load v/s Deflection (beam with steel fibers with GGBS

\section{Discussion Based on Results}

From the obtained results it is found that, the $\mathrm{CC}$ post tensioned beam undergo large deflection as compared to concrete with GGBS and SFRC post tensioned beams. The first crack width is also maximum in the case of CC post tensioned beam as compared to concrete with GGBS and SFRC post tensioned beams. Also the ultimate load carrying capacity of CC post tensioned beam is less compared to GGBS and SFRC post tensioned beams.

\section{Conclusions}

1. The ultimate load carrying capacity of conventional concrete (CC) Post-tensioned beam is $153 \mathrm{kN}$, where as in the case of GGBS Post-tensioned beam is $174 \mathrm{KN}$. i.e. the strength has increased about $13.72 \%$.

2. SFRC Post-tensioned Beam has a maximum load carrying capability of $180 \mathrm{kN}$, which is $17.63 \%$ higher than CC Beam. Also the ultimate load carrying capacity of SFRC with GGBS Post-tensioned beam is $196 \mathrm{kN}$, which is $28.10 \%$ greater than CC beam

3. The first crack width for CC beam is $0.6 \mathrm{~mm}$, where as in GGBS beam and SFRC with GGBS is $0.4 \mathrm{~mm}$ and $0.3 \mathrm{~mm}$ respectively.

4. Hence incorporation of steel fibre in concrete reduces the crack width and propagation of cracks.

5. Hence, the results suggest that adding GGBS to concrete increased the beam's load carrying capability significantly.

6. The environmental harm caused by cement manufacture can be reduced by substituting GGBS.

7. And the addition of fibre in concrete has serious impact on the flexural strength of the beam.

\section{Scope for Future Work}

The same project can have carried out in analytical, and compare the result with experimental results.

1. The post tensioned beam can be tested for uniformly distributed load.

2. Since the experiment is carried out for flexural behavior, the shear behavior can also be tested.

3. Since the experiment is carried out for $10 \%$ of GGBS, with different proportions and with the different types of mineral admixtures can also be used and tested.

4. By stressing the post tensioned beams with different ratios can also be tested. 


\section{References}

1. Arvind Nakum, Vishal Patel, And Vatsal Patel Civil Engg. Dept. A D I T “High Strength Concrete Incorporating Ground Granulated Blast Furnace Slag And Steel Fibres: A Review" International Journal Of Structural And Civil Engineering Research Vol. 4, No. 2, May 2015.

2. S.P.Sangeetha, Dr. P.S.Joanna "Flexural Behaviour Of Reinforced Concrete Beams With Ggbs" International Journal Of Civil Engineering And Technology (Ijciet), Volume 5, Issue 3, March (2014).

3. Hyeong Jae Yoon And Minehiro Nishiyama, "Behavior Of Pre-Tensioned Concrete Beams Using Steel Fibre Reinforced Concrete" Kyoto University Japan.

4. Konda Rushi Kesava Reddy, Dr. K. Chandrasekhar Reddy, "Flexural Behavior Of Steel Fibre High Strength Concrete Beams" International Journal Of Science And Research (Ijsr) Volume 4 Issue 5, May 2015.

5. Qiaoyan Guan, Peng Zhang And Xiaopeng Xie, "Flexural Behavior Of Steel Fibre High Strength Concrete Beams" June 05, 2013. Issn

6. Abdolluah Namdar, Ideris Bin Zakaria, Azimath Bt Hazeli, Syed Javid Azimi, Abdul Syukor Bin Abd. Razak An Experimental Study On Flexural Strength Enhancement Of Concrete By Means Of Small Steel Fibre 26 (2013)

7. Kalappa.M.Sutar. “Experimental Studies On Pozzolanic Action Of Ggbs And Strength Properties Of Ggbs Concrete. International Journal For Innovative Research In Science \& Technology. Volume 1, Issue 12, May 2015.

8. Shubham Jain, Gunja"N Kumar "Effect Of Fiber Volume And Partial Replacement Of Cement By Ggbs On Flexural Strength Of Sifcon” International Journal Of Engineering Research \& Technology (Ijert). Vol. 4 Issue 06, June-2015.

9. M.S. Shetty, "Concrete Technology” S. Chand Publication, 6th Edition 2011.

10 N Krishna Raju. "Pre Stressed Concrete" 5th Edition.

11.IS:456-2000, Plain And Reinforced Concrete. Code Of Practice. Bureau of Indian Standards, New Delhi.

12. IS:10262-2009, Concrete Mix Proportioning- Guidelines, Bureau of Indian Standards, New Delhi.

13.IS:1343- 1980, Code Of Practice For Pre Stressed Concrete, Bureau of Indian Standards, New Delhi.

14.IS:6006-1983, Specification For Uncoated Stress Relieved Strand For Pre Stressed Concrete, Bureau of Indian Standards, New Delhi.

15.IS:383-1997, Specification For Coarse And Fine Aggregates From Natural Sources For Concrete, Bureau Of Indian Standards, New Delhi.

16.IS:516-1959, Method of Tests of Strength of Concrete, Bureau of Indian Standards, New Delhi 